\title{
'Evangeline' Strawberry
}

\author{
A.R. Jamieson ${ }^{1}$ and N.L. Nickerson ${ }^{2}$ \\ Agriculture and Agri-Food Canada, Atlantic Food and Horticulture Research \\ Centre, 32 Main Street, Kentville, NS, B4N 1J5, Canada
}

\author{
K.R. Sanderson ${ }^{3}$ \\ Agriculture and Agri-Food Canada, Crops and Livestock Research Centre, 440 \\ University Avenue, Charlottetown, PE, C1A 4N6, Canada
}

\section{J.-P. Privé ${ }^{4}$}

Agriculture and Agri-Food Canada, Senator Hervé J. Michaud Research Farm, 1045 St. Joseph Road, P.O. Box 2069, Bouctouche, NB, E4S 2J2, Canada

\section{R.J.A. Tremblay ${ }^{5}$}

N.B. Department of Agriculture, Fisheries, and Aquaculture, P.O. Box 6000, Fredericton, NB, E3B 5H1, Canada

\section{P. Hendrickson ${ }^{6}$}

Nfld. Department of Forest Resources and Agrifoods, P.O. Box 2006, Corner Brook, NL, A2H 6J8, Canada

\section{Additional index words. Fragaria $\times$ ananassa, fruit breeding, fruit firmness}

The 'Evangeline' strawberry (Fragaria $\times$ ananassa Duchesne) was commercially introduced in Canada in May 1999 by the Atlantic Food and Horticulture Research Centre of Agriculture and Agri-Food Canada. 'Evangeline' ripens in early season, offering growers an alternative to 'Veestar' and 'Annapolis' with firmer fruit and a more attractive, conical shape. Fruit of 'Evangeline' are darker in color than 'Veestar' and 'Annapolis' and berries are larger than 'Veestar' but smaller than 'Annapolis'. All three cultivars produce similar yields. 'Evangeline' is named for the heroine of the narrative poem Evangeline: A Tale of Acadie written by Henry Wadsworth Longfellow based on the deportation of Acadians in 1755 from Grand Pré, in the Annapolis Valley, Nova Scotia.

\section{Origin}

'Evangeline', tested as K93-1, is a seedling from a K88-4xNYUS 119 cross made under the direction of A.R. Jamieson in 1992 at Kentville, N.S. Both parents ripen in the early season. The cross was intended to produce early season genotypes combining the productivity and flavour intensity of K88-4 with the increased fruit firmness of NYUS 119. The cultivar 'Honeoye' (Sanford et al., 1982), notable for its productiv-

Received for publication 27 Feb. 2004. Accepted for publication 24 March 2004. Atlantic Food and Horticulture Research Centre Contribution no. 2278. We thank K.B. McRae, S. Fillmore, and B. Walker for assistance with experimental design and analysis. For technical support, we thank A.C. Brydon, M. Graves, P. Rand, and R.J. Davies. For helpful comments on the manuscript, we thank Charles Forney and John DeLong.

${ }^{1}$ Fruit breeder. Corresponding author; e-mail jamiesona@agr.gc.ca.

${ }^{2}$ Mycologist.

${ }^{3}$ Horticulturist.

${ }^{4}$ Fruit crop physiologist.

${ }^{5}$ Small fruit specialist.

${ }^{6}$ Horticulturist (retired). ity over a wide geographic area, is predominant in the pedigree (Fig. 1). Seedling plants of the cross were planted at Sheffield Mills, Kings County, N.S., in Spring 1992 and 'Evangeline' was selected for its firm and attractive fruit in June 1993 by A.R. Jamieson.

\section{Description and Performance}

'Evangeline' has been tested in Atlantic Canada in regional trials planted in 1996, 1997, and 1999 in Nova Scotia, New Brunswick, Prince Edward Island, and Newfoundland. Trials located in Atlantic Canada consisted of matted rows developed from seven plants set $50 \mathrm{~cm}$ apart. A 3-m section of each row, centered on the midpoint, was harvested two times per week. Each site had three replicate rows. The data collected included marketable and unmarketable yield, and fruit weight based on a 25-fruit sample from each row on each harvest date. Mean fruit weight and mean harvest date were calculated on each row and values were weighted

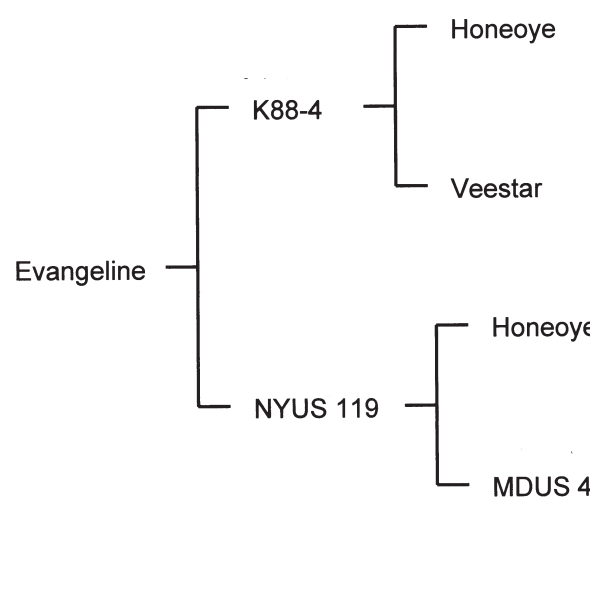

Fig. 1. Pedigree of 'Evangeline' strawberry. by yield as described by Moore (1970) to give seasonal means. All statistics were calculated with Genstat 5.31 (Payne, 2000).

Fruit firmness was determined by penetration using an Ametek firmness tester (Ametek, Hunter Spring Division, Hatfield, Pa.) with a 6 mmo.d. v-notched tip or an Imada firmness tester (Imada Inc., Northbrook, Ill.) with a 7.5-mm o.d. v-notched tip. Secondary berries, red-ripe, were carefully selected to avoid over-ripe fruit and picked to avoid bruising. The maximum force that occurred during insertion of the probe $6 \mathrm{~mm}$ into the sides of each of 10 fruit was recorded. Two measurements were made per berry (darker and lighter red sides) and these were averaged to give a mean berry value. The 10 means were averaged and the standard error was calculated to show the variation around the cultivar mean.

Plants of 'Evangeline' are vigorous and they runner freely. Matted rows of 'Evangeline' are as dense as 'Annapolis' and more open than 'Sable'. Crown size is medium and larger than 'Sable'. Leaves are trifoliate: the central leaflet is longer than wide (1.2 length to 1.0 width), with an acute base and acute serrations. Leaflet serrations of 'Annapolis', 'Sable', and 'Veestar' are obtuse. 'Evangeline' leaflets tend to be flat in profile whereas the leaflets of 'Annapolis', 'Sable', and 'Veestar' are cupped. 'Evangeline' leaf petioles are medium long with a sparse to medium density of hairs which tend to be upwardly oriented as opposed to the perpendicularly oriented hairs of 'Annapolis', 'Sable', and 'Veestar'. Flower clusters are produced on medium long, stiff peduncles and flowers open even with or slightly beneath the canopy. The stiff peduncles hold the fruit above the ground, unlike the more prostrate 'Annapolis', 'Sable', and 'Veestar'. 'Evangeline' flowers are larger than those of 'Annapolis', 'Sable' and 'Veestar' and petals are longer than wide (1.2 length to 1.0 width). The petals of 'Annapolis' are also longer than wide but 'Sable' and 'Veestar' petals are wider than long.

'Evangeline' fruit weight, when averaged over the harvest season, is typically larger than 'Veestar', similar to 'Sable', but smaller than 'Annapolis' (Table 1). Fruit are typically conic in shape with a raised calyx (Fig. 2). The larger primary fruit may have a broad tip giving a wedge shape, as well as a neck. 'Evangeline' fruit are more even in shape than 'Veestar' and 'Sable'. The calyx is typically large and dark green and its diameter is greater than the diameter of the fruit. Calyx removal from the fruit (hulling) is easy to medium. Fruit surface is glossy, medium to dark red with a light to medium red interior flesh color. Achenes are inserted below the surface of the fruit. The uniform conic shape,

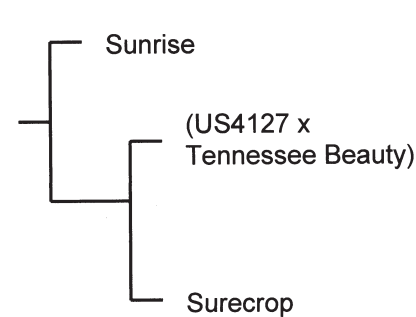


Table 1. Fruit production ${ }^{2}$ of 'Evangeline' strawberry and standard cultivars for 1997 to 2000 averaged over sites in Atlantic Canada.

\begin{tabular}{|c|c|c|c|c|}
\hline \multirow[b]{2}{*}{ Cultivar } & \multicolumn{2}{|c|}{ Yield $\left(\mathrm{t} \cdot \mathrm{ha}^{-1}\right)$} & \multirow{2}{*}{$\begin{array}{c}\text { Wt/fruit } \\
(\mathrm{g})\end{array}$} & \multirow{2}{*}{$\begin{array}{c}\text { Mean } \\
\text { harvest } \\
\text { (day of year) }\end{array}$} \\
\hline & Marketable & Unmarketable & & \\
\hline \multicolumn{5}{|c|}{$1997(\text { Sites } 1,2,3,4,5 ; \text { trial } 1)^{y}$} \\
\hline Evangeline & $3.8 b^{x}$ & $0.4 \mathrm{~b}$ & $10.1 \mathrm{a}$ & $197.6 \mathrm{a}$ \\
\hline Sable & $6.6 \mathrm{a}$ & $0.8 \mathrm{a}$ & $10.7 \mathrm{a}$ & $197.7 \mathrm{a}$ \\
\hline Veestar & $5.4 \mathrm{a}$ & $0.9 \mathrm{a}$ & $8.3 \mathrm{~b}$ & $196.8 \mathrm{~b}$ \\
\hline \multicolumn{5}{|c|}{$1998($ Sites 2,3,4,5; trial 1) } \\
\hline Evangeline & $4.1 \mathrm{a}$ & $1.0 \mathrm{~b}$ & $9.2 \mathrm{a}$ & $186.0 \mathrm{a}$ \\
\hline Sable & $5.5 \mathrm{a}$ & $2.0 \mathrm{a}$ & $9.7 \mathrm{a}$ & $185.5 \mathrm{a}$ \\
\hline Veestar & $4.6 \mathrm{a}$ & $1.8 \mathrm{a}$ & $9.4 \mathrm{a}$ & $185.4 \mathrm{a}$ \\
\hline \multicolumn{5}{|c|}{1998 (Site 1 ; trial 2) } \\
\hline Evangeline & $11.2 \mathrm{~b}$ & $0.4 \mathrm{~b}$ & $13.2 \mathrm{a}$ & $179.2 \mathrm{~b}$ \\
\hline Sable & $17.2 \mathrm{a}$ & $2.5 \mathrm{a}$ & $11.7 \mathrm{~b}$ & $180.3 \mathrm{a}$ \\
\hline Veestar & $11.1 \mathrm{~b}$ & $0.9 \mathrm{~b}$ & $8.0 \mathrm{c}$ & $178.3 \mathrm{~b}$ \\
\hline \multicolumn{5}{|c|}{$2000($ Sites 1,2,6; trial 3) } \\
\hline Evangeline & $4.8 \mathrm{c}$ & $0.4 \mathrm{~b}$ & $9.7 \mathrm{~b}$ & $192.4 \mathrm{a}$ \\
\hline Sable & $9.2 \mathrm{a}$ & $1.4 \mathrm{a}$ & $9.6 \mathrm{~b}$ & $191.7 \mathrm{a}$ \\
\hline Annapolis & $5.9 \mathrm{~b}$ & $0.5 \mathrm{~b}$ & $11.9 \mathrm{a}$ & $192.8 \mathrm{a}$ \\
\hline
\end{tabular}

${ }^{2}$ Trial 1 data for 1997 and 1998 from plots established in 1996; trial 2 data for 1998 from plots established in 1997; trial 3 data for 2000 for plots established in 1999. Data from entire trials, containing 14 to 16 cultivars or selections, were used in the Analysis of Variance.

yTrial locations: 1. Kentville, N.S.; 2. Charlottetown, P.E.I.; 3. Bouctouche, N.B.; 4. Pynn's Brook, Nfld.; 5, Grand Lake, N.B.; 6. Belleisle Creek, N.B.

${ }^{\times}$Mean separation within columns and years by least significant difference test at $P \leq 0.05$.

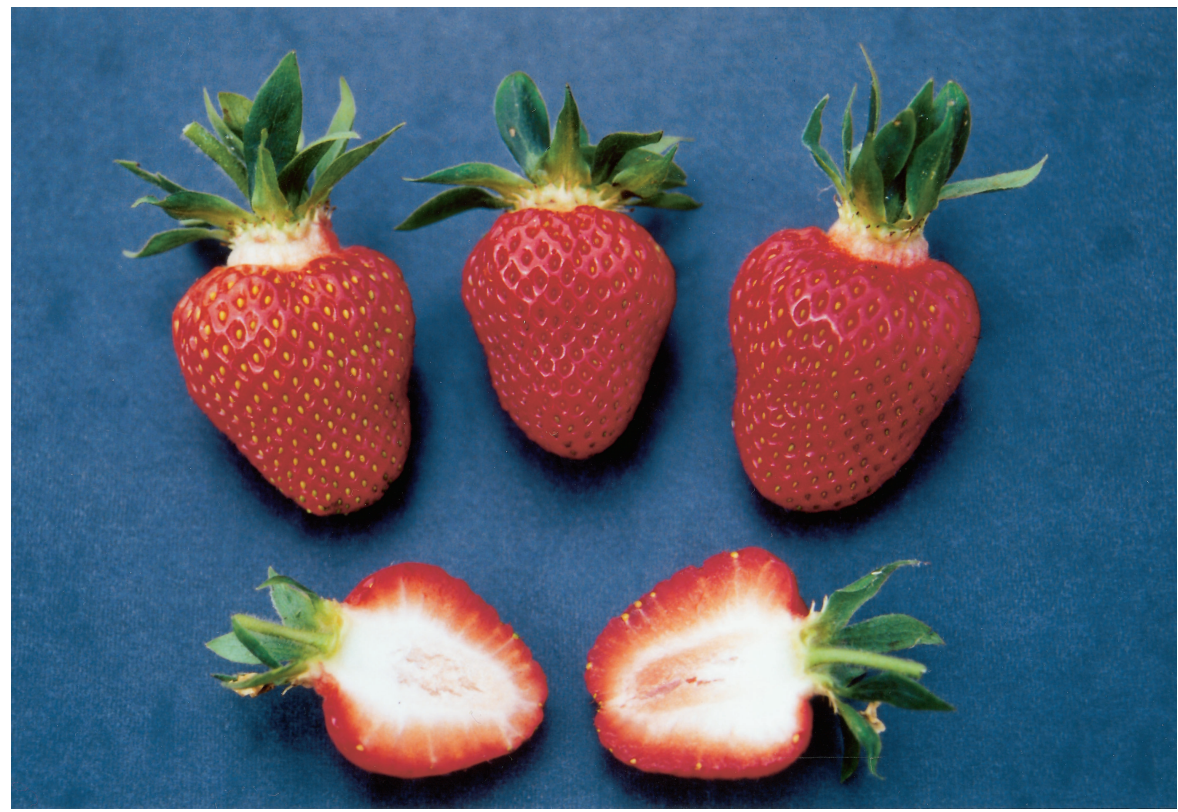

Fig. 2. Primary ‘Evangeline’ strawberries.

Table 2. Mean fruit firmness of 'Evangeline', 'Sable', 'Honeoye', and 'Veestar' strawberries harvested red-ripe.

\begin{tabular}{lcc}
\hline Cultivar & $\begin{array}{c}\text { Firmness }^{2} \\
(\mathrm{~N})\end{array}$ & SE \\
\hline 2002 & & \\
$\quad$ Evangeline & 3.6 & 0.06 \\
Sable & 3.4 & 0.14 \\
Honeoye & 3.3 & 0.08 \\
$\quad$ Veestar & 3.1 & 0.15 \\
2003 & & \\
$\quad$ Evangeline & 4.6 & 0.17 \\
$\quad$ Sable & 4.4 & 0.10 \\
\hline
\end{tabular}

${ }^{2}$ Fruit firmness in Newtons as determined by penetration in 2002 using an Ametek firmness tester with a 6-mm o.d. v-notched tip and in 2003 using an Imada firmness tester with a 7.5-mm o.d. v-notched tip . The maximum force that occurred during insertion of the probe $6 \mathrm{~mm}$ into both sides of each of 10 fruit was recorded and averaged.
$19.7 \mathrm{~d}$ for 'Sable' in 2000, averaged over three sites. Short duration early season varieties are preferred by some growers because they can finish harvesting those fields by the time the more productive mid-season varieties are peaking. In the Atlantic regional trials, fruit yields have been low to medium, similar to 'Veestar' but less than 'Sable' (Table 1).

\section{Disease Response}

'Evangeline' is resistant to races A-4 and A-7 and intermediate in its reaction to A-3 of Phytophthora fragariae var. fragariae, however, this pattern will not offer practical resistance in eastern Canada where A-6 predominates (Nickerson and Jamieson, 1995). In field plots at Kentville, 'Evangeline' plants have demonstrated resistance to leaf scorch [caused by Diplocarpon earliana (Ellis \& Everh.) F.A. Wolf], and moderate resistance to leaf spot [caused by Mycosphaerella fragariae (Tul.) Lindau] and powdery mildew [caused by Sphaerotheca macularis (Wallr.:Fr.) Jacz. f. sp. fragariae]. Tolerance to fruit rot (caused by Botrytis cinerea Pers.:Fr.) is greater than 'Sable' and may result from the stiff stalks which hold the fruit above the soil. Virus diseases of strawberries are uncommon in Atlantic Canada, and the virus tolerance of 'Evangeline' is unknown. Green petal disease (caused by clover phyllody phytoplasma) is common, however, and plots of 'Evangeline' have contained few plants with symptoms indicating a moderate level of resistance.

'Evangeline' appears to be well adapted throughout eastern Canada and northeastern U.S. 'Evangeline' will be of value as a firmfruited alternative to other early season cultivars providing attractive, richly colored berries for local and regional markets.

\section{Availability}

Certified 'Evangeline' plants are being propagated under royalty agreements with licensed nurseries, the names of whom will be supplied upon request. The Atlantic Food and Horticulture Research Centre has been granted Plant Breeder's Rights for 'Evangeline' (Certificate No. 0617) and a U.S. plant patent application has been filed. Nurseries interested in securing a propagating license may contact A.R.J., Agriculture and Agri-Food Canada, Atlantic Food and Horticulture Research Centre, 32 Main St., Kentville, NS, B4N 1J5, Canada or jamiesona@agr.gc.ca.

\section{Literature Cited}

rated medium, and 'Veestar' is rated as soft. First harvested primary fruit of 'Evangeline' are very firm. Field ratings of berry skin toughness are medium for 'Evangeline', similar to 'Annapolis'. Pressure tests have verified the greater firmness of 'Evangeline' compared with other early cultivars (Table 2).

'Evangeline' ripens in the early season within a day of 'Veestar' and 'Sable' (Table 1). The duration of harvest is relatively short, similar to 'Annapolis' the leading early season cultivar in eastern Canada. The harvest duration was 17.7 $\mathrm{d}$ for 'Evangeline', $17.6 \mathrm{~d}$ for 'Annapolis', and
Moore, J.N. 1970. Fruit size of strawberry cultivars. Fruit Var. Hort. Dig. 24:58-62.

Nickerson, N.L. and A.R. Jamieson 1995. Canadian races of the red stele root rot fungus, Phytophthora fragariae var. fragariae. Adv. Strawberry Res. 14:31-35.

Payne, R.W. (ed.). 2000. The Guide to GenStat. part 2. Statistics. VSN Intl. Ltd. Oxford, U.K.

Sanford, J.C., D.K. Ourecky, J.E. Reich, and H.S Aldwinckle. 1982. 'Honeoye' and 'Canoga' strawberries. HortScience 17:982-984. 